\title{
Fort McKay First Nation's Involvement in Reclamation of Alberta's Oil Sands Development
}

\author{
K. Buffalo, Fort McKay, Canada \\ C.E. Jones, Stantec Consulting Ltd., Canada \\ J.C. Errington, JC Errington and Associates Ltd., Canada \\ M.I.A. MacLean, Stantec Consulting Ltd., Canada
}

\begin{abstract}
Fort McKay is a Cree, Dene and Métis community situated in the epicentre of Alberta's oil sands developments and the people of Fort McKay believe that this development is limiting their ability to carry out cultural activities within their Traditional Lands and that this has significant adverse effects on the maintenance of their cultural heritage.
\end{abstract}

The Community has existed on their Traditional Lands for generations and places great value on the land and all that the land supports. Fort McKay has major concerns associated with both the "loss of land" and the condition of this land following mine closure and reclamation.

The existing approved and proposed mine developments will ultimately occupy hundreds of thousand hectares of land and will not be fully reclaimed until the latter half of this century, with the likelihood that a further 10 to 20 years will be needed before the land can be certified as reclaimed. This means that the land occupied by these mines will be alienated from two to three generations of Fort McKay people.

Fort McKay and the group of specialist consultants employed to work on behalf of the Community have worked closely with the Alberta government and oil sands developers to express the Community's concerns and to push both industry and government to work towards meeting the immediate and long term objectives.

Although Fort McKay cannot take credit for the recent improvements in mine closure regulation and performance, Fort McKay has certainly had a strong voice which has helped lead to a number of changes in approval conditions. Changes which we have seen over recent years include improved regulations for salvage and replacement of topsoil, recent changes to the management of fluid fine tailings and the requirement to initiate large scale trials of techniques to reclaim land to peat accumulating wetlands (fens and bogs).

In the future, Fort McKay will continue to strive for faster reclamation that will restore the land to premining conditions, will seek the complete elimination of fluid fine tailings especially those which will be stored under a water cap in an end pit lake, will seek to ensure that acceptable water quality will be achieved within a reasonable timeframe following closure and will seek to ensure that the reclaimed landscape will support the full range of traditional uses including medicinal plants, berries, hunting, fishing and trapping.

\section{Introduction}

The Athabasca Oil Sands mineable area occurs in the Municipality of Wood Buffalo located in Northeastern Alberta, Canada. This Municipality has a population of over 103,000 inhabitants; with the population more than doubling between the years of 2000 and 2008 (RMWB 2008) Population growth is attributed primarily to investment in the oil sands industry, attracting workers and their families to the region.

Fort McKay is a Cree, Dene and Métis community located in the heart of mineable oil sands. This community is home to 862 inhabitants (RMWB 2008), and is almost completely encircled by oil sands developments. There are currently eight oil sands operators within a $20 \mathrm{~km}$ radius of the community, with total disturbance of approximately 50,000 ha or $39.1 \%$ of this area (Figure 1). 


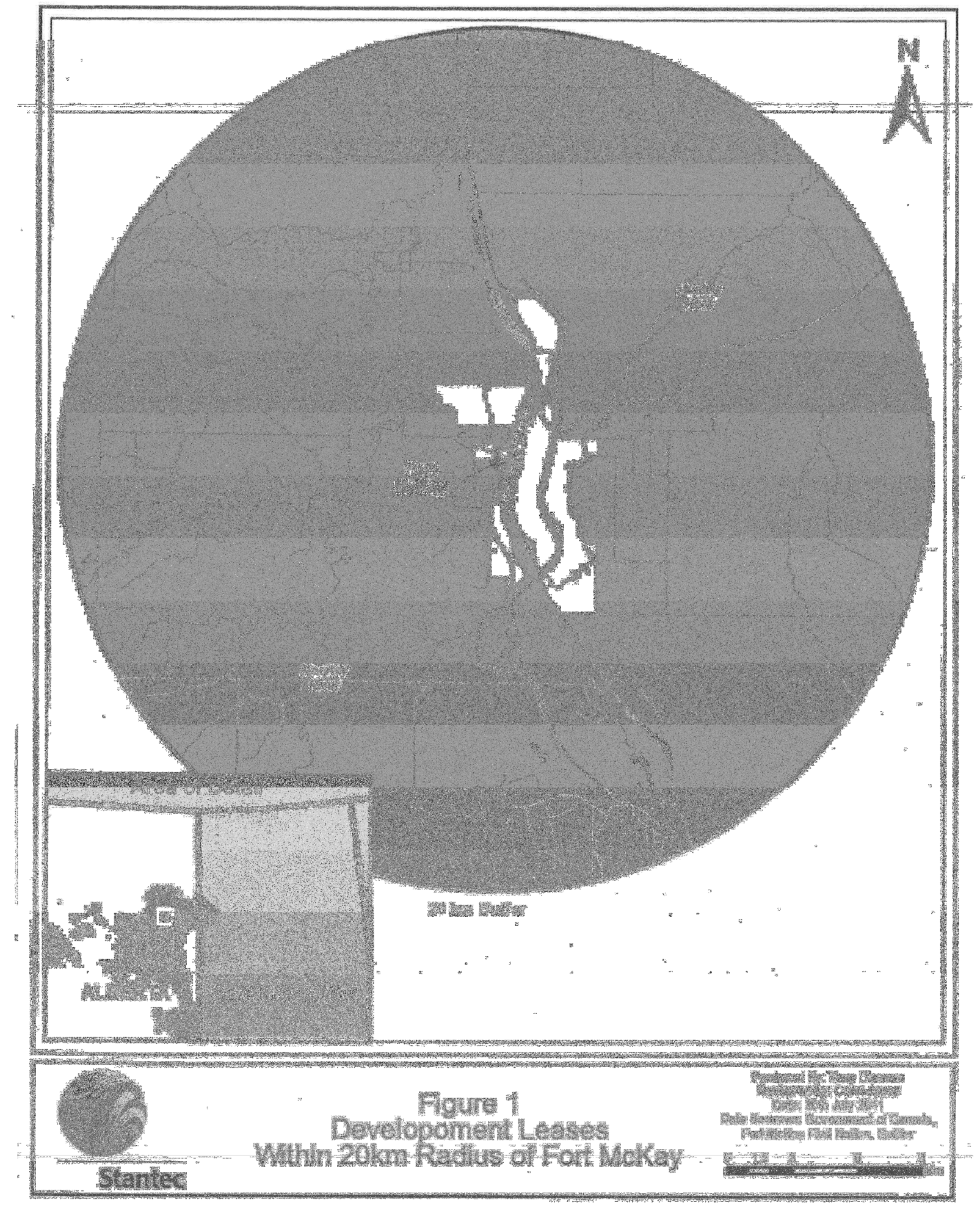

Figure 1 Oil Sands Disturbances within a $20 \mathrm{~km}$ radius of Fort McKay AB 
This percentage of disturbed land is likely to increase to $90.5 \%$ as additional planned and proposed mines are developed over the next couple of decades.

The stressors of oil sands development and rapidly increasing population in the region have had a major effect on the traditional way of life for residents of Fort McKay (Fort McKay IRC, 2010a). In the past, the traditional lands were used for activities such as hunting, trapping and fishing, and plants were harvested for food and medicinal purposes. At present, it is becoming increasingly difficult for the community to access any of the remaining traditional lands. In addition, many Fort McKay residents have joined the wage based economy, working in jobs directly associated with the oil sands industry.

The Community (represented by Fort McKay's Industry Relations Corporation, now the Fort McKay Sustainability Department) has taken a proactive approach to the review of all project applications, regulatory guidance documents and legislation, providing valuable recommendations to industry and government on how Fort McKay would like to see oil sands leases developed and most importantly how they will be reclaimed once active mining and bitumen extraction has come to an end.

\section{Fort McKay's Views on Reclamation Objectives}

Because of the Fort McKay's close proximity to oil sands development the community has played, and will continue to play, an integral role in the review of oil sands projects in the region. One of the most pressing concerns for community members involves the reclamation of land disturbed for mining, land that residents once relied on for their sustenance.

The land is very important to the Community of Fort McKay (Fort McKay IRC, 2010a). Fort McKay often refers to the environment as "land" but this term reflects both land and water and also includes all of the biological components of the environment. "For many holders of traditional knowledge, land is inseparable from culture" (Garibaldi, 2006).

Reclamation is the primary method of mitigation of mining impacts on the environment. When the oil sands industry has asked for guidance from the Elders of the Fort McKay Community about reclamation of the land disturbed by oil sands mining, the answer has been "to return the land to the way it was". Additionally, the Community believes that reclamation should occur quickly after disturbance occurs, allowing people access to the land and traditional uses much sooner.

The reclamation objectives of the Community of Fort McKay differ in some respects to the reclamation objectives of Alberta Environment (AENV). The primary objective of reclamation, as described by AENV, is to return land "to an equivalent land capability" (Alberta Conservation and Reclamation Regulation AR 115/93). Unfortunately, equivalent land capability in many cases may not reflect the condition of the land before mining and development occurred, many aspects of the original landscape of the boreal forest have not been recreated, such as muskeg (organic wetlands). Current closure and reclamation plans reduce the amount of wetlands in the final landscape, replacing them with upland forests and large scale end-pit lakes, which significantly change the reclaimed landscape from that which existed before oil sands development.

With regard to Fort McKay's concern regarding the time that elapses between mining and reclamation the Province of Alberta may be more closely aligned with Fort McKay's objectives. Recently the regulators have adopted strategies to push industry towards developing ways to achieve progressive reclamation, or being able to reclaim land shortly after it has been mined. The result of this would allow the land to become available to users sooner. Recently, AENV has unveiled new definitions for the classification of land destined to be reclaimed in an effort to better track the reclamation progress (Alberta Environment, 2009). The Alberta Energy Resources Conservation Board (ERCB) has introduced a new directive to manage the volume of fluid tailings on mine sites, which if effective, could result in the creation of a drier landscape that maybe suitable for reclamation years or decades sooner.

\section{Fort McKay's Key Reclamation Concerns}

The Community of Fort McKay has a number of concerns about the current methods of reclamation and the pace at which reclamation is proceeding. First and foremost of these concerns is wanting the land to be returned to the way it was prior to disturbance by industry. Community members view the landscape as an integrated whole and the absence of muskeg components in the reclaimed land is of great concern to the 
people who have subsisted for generations on this land. Very importantly, the Community is also concerned about who will be responsible for the land once mining is complete. If reclaimed land is not designed to be self-sustaining, who will be responsible for the ongoing maintenance of these sites? Fort McKay has lived on this land for generations and expects to continue to do so after mining is complete. In the words of one Elder "My hope is that reclamation will benefit our great grandchildren for the next seven generations" (Fitzpatrick, 2004)

Community members feel a spiritual connection to the land and the plants and animals that live and grow there, and some believe that reclamation will not be able to recreate the spirit in the land leading them to question the value of medicinal plants, etc., grown on the reclaimed landscape. Additionally, many Community members question the potential for contaminants in the landscape and they believe that once this land is reclaimed it will not be safe for animals and people to use.

Additional to these concerns is the question of timing of reclamation and when the disturbed landscape will be adequately reclaimed and allow the Community to use the land for traditional purposes. Without access to their Traditional Lands the Community runs the risk of traditional knowledge being permanently lost due to the inability of Elders and others to conduct traditional activities on the land and in doing so, pass this knowledge on to younger generations.

These concerns are further examined below.

\subsection{Put the Land Back the Way It Was}

Oil sands mining activities remove land to expose and extract bitumen and then at closure substitute a different landscape. The newly reclaimed landscape alters the shape of the land and the proportion of wetlands and uplands significantly. The flow of water courses is changed, the types of wetlands are altered and the size of wetlands is reduced and current technology is not available for re-establishing muskeg. Final landscapes will also include higher percentages of lakes which will be much larger and deeper than those found on undisturbed, traditional lands.

An increased proportion of upland forest will have a detrimental effect on plant diversity, certain plants that are culturally significant, rare, and some that are important to wildlife may be absent from the landscape. In addition, most rare plants and many traditionally important plant species that are present in the original landscape occur only on organic wetlands or muskeg, which have yet to be successfully re-established.

Increased proportions of upland forests may affect wildlife populations, with certain species thriving in these conditions, while others more suited to organic wetlands may be less abundant. The increased proportion of upland forests will potentially lead to significant modifications to the hydrology in the region. Organic wetlands play an important role in regulating water flow and preventing erosion during heavy rainfall or snow-melt conditions. Organic wetlands also play a significant role in water storage during dry seasons and years. In the reclaimed landscapes water storage will primarily be accomplished using large, open water endpit lakes. These lakes will be much more susceptible to evaporation and could lead to significant water losses from the landscape. This water loss from the landscape may be exacerbated by the higher rate of evapotranspiration in upland forests, which will form a greater percentage of the closure landscape than that prior to development.

\subsection{Muskeg is Important; Water is Important}

In the boreal forest landscape much of the water is contained in muskeg (organic wetlands). Currently the technology does not exist to re-establish muskeg in the reclamation landscape and the types and amounts of wetland reclaimed in the post-closure landscape will be significantly different from those that occur naturally. Concerns have been expressed that salinity levels in water coming off of upland sites will prohibit the development of plants critical in establishing muskeg.

Current reclamation plans do not address the containment of soils that leach salts into drainage waters. At the present, water discharges from pit lakes are designed to go directly into major rivers. If pit lakes can be demonstrated to successfully dilute/reduce salinity in drainage waters making them suitable for direct discharge, Fort McKay questions if perhaps these waters can instead be directed into constructed organic wetlands to replace portions of lost muskeg. 
Water and water quality in the reclamation landscape is something that is of key importance to the Community of Fort McKay. In the simplest terms, if the water is not fit for human or wildlife uses or consumption how can reclamation be deemed successful? The usefulness of the reclaimed land will be eliminated if the water quality is poor.

\subsection{Who Will Be Responsible for the Land When Mining is Complete?}

The Community of Fort McKay will continue to exist after mining and reclamation operations have ceased. Concerns have been raised regarding responsibility of residual environmental issues after mine closure. More specifically, Fort McKay believes that these sites should be self-sustaining after closure and ongoing maintenance of structures in the designs approved for these projects will not be an acceptable option. This concern extends to the dykes that contain tailings and to the "pillars" of land that contain the end pit lakes. Long term water treatment of discharge waters is also a concern of the Community, they support the design of waste materials to eliminate or significantly reduce the release of salts and other contaminants into the water systems of the reclaimed landscapes.

\subsection{You Can't Put the Spirit Back in the Land}

Many residents of Fort McKay hold close spiritual beliefs in the land and the wildlife and plants that live and grow there. To explain the importance of these ties one community member discussed the land in this way, "Muskeg is connected through water to the rest of the earth. With that comes our spiritual values and how we are connected and respect the earth." (Fitzpatrick, 2003) Some community members feel that once the land has been reclaimed it will have lost "spirit" and medicinal and other plants will not grow as well or be as effective. They believe the loss of "spirit" will be a permanent cost of oil sands mining and cannot be mitigated through reclamation.

\subsection{Reclamation is Too Slow}

At the current pace of reclamation, most mining projects located adjacent to the Community of Fort McKay will not be fully reclaimed until 2060, with an additional 15 to 20 years of monitoring required to obtain reclamation certification. This means that these sites will be inaccessible to three generation of Fort McKay residents, representing a significant cultural loss.

The pace of reclamation varies between mine plans. Some mining operations see a great deal of reclamation occurring early in the mine plan while others do not, preferring instead to complete the bulk of their reclamation activities once active mining operations have ceased.

This concern is best illustrated by examining three active and proposed mining operations in close proximity to Fort McKay. Mine A, is a proposed mine whose current mine plan has disturbance occurring over a 30year period, however during that period less than $10 \%$ of the land disturbed is reclaimed. Reclamation is planned, primarily, for the 10 year period following the end of mining.

Mine B, another proposed mine, has a longer period of disturbance with mining activities occurring over a 40 -year span. During that period approximately $25 \%$ of the land is under reclamation with the remaining $75 \%$ being reclaimed over the next 20 years after new mine disturbance has ceased.

While Mine B has a higher percentage of reclaimed land in the earlier stages of operation both mines have an extremely slow pace of reclamation over the long term. This is a stark contrast to Mine C, which is currently operating. After 2017, the amount of land reclaimed in Mine $\mathrm{C}$ is equal to the amount of land disturbed on a year-to-year basis.

It is evident that the mine design will determine the pace of reclamation and that a critical factor in the pace of reclamation is controlled by the tailings management. A recent regulatory change, the ERCB's Directive 074-Tailings Performance Criteria and Requirements for Oil Sands Mining Schemes, is pushing oil sands operators to more stringent management of fluid tailings, potentially producing a drier landscape in the process, a landscape that may be more suitable for reclamation at earlier stages of mine life. 
While over 530 square kilometres of land are presently disturbed by oil sands projects some that have been in operation for over 40 years, only 104 ha have been issued a reclamation certificate to date. Fort McKay's concern regarding the slow pace of reclamation is clearly illustrated in this statistic.

\section{Fort McKay's Involvement in Reclamation Certification}

Fort McKay has had the ability to influence government's regulation of oil sands development and reclamation through review of company applications under the EPEA. In addition, through environmental agreements between Fort McKay and individual oil sands companies, Fort McKay has been able to influence companies to pay more attention to Fort McKay's reclamation expectations. Nevertheless, at present, Fort McKay has no formal involvement in the Province of Alberta's reclamation certification review and final decision making process. The current certification process contains provision for the involvement of "landholders" in the certification inquiry, but does not permit First Nations the same opportunity. Because Fort McKay First Nations will continue to have rights under Treaty 8 to continue to carry out its traditional use following mining, it clearly must have a say into the state of the land following reclamation. While the ultimate decision on whether or not the land has been satisfactorily reclaimed will likely remain with the Alberta government, Fort McKay will continue to strive for formalized involvement in the reclamation certification decision process.

\subsection{Fort McKay's Recommendations}

There have been a number of common themes in the recommendations on reclamation that Fort McKay has made to oil sands developers through the course of consultation, review of project applications and participation in regional groups such as Cumulative Environmental Management Association (CEMA) over the past decade. Fort McKay has been encouraged by some modifications to the EPEA conditions applied to many of the operations and by the ERCB Directive 074 to all of the mining operations. As a result of these regulatory changes, some of the recommendations of Fort McKay on reclamation of the landscape are beginning to be addressed while others are still being discussed.

\subsection{Topsoil Salvage and Replacement}

Mining sites when reclaimed must be covered with a suitable amount of subsoil and topsoil. Oil sands developers are required to pre-strip and stockpile soil materials suitable for reclamation cover material. During reclamation soils are applied as prescribed for the type of landscape that is planned. Fort McKay had argued that in many cases the thickness of topsoil and subsoil is unacceptable and will be incapable of supporting a productive landscape. The stripping and placement of soil materials that is now required by AENV should improve the resulting upland forest development on the reclaimed landscape.

\subsection{Muskeg (Organic Wetlands)}

The development of oil sands leases results in the destruction of extensive areas of muskeg. To date no developer has been able to successfully re-establish these wetlands in a reclaimed landscape. Fort McKay has been keenly aware of these facts for sometime as these wetlands and muskeg are a dominant important feature in the boreal landscape. Fort McKay has recommended to government that oil sands developers conduct in wetlands research in an attempt to find ways to more successfully integrate muskeg into a reclaimed landscape. AENV now requires developers to "undertake or participate in a study on reclamation techniques that examines the viability of bog/fen creation for a portion of the final landscape" (EPEA approval conditions, 2007). Two experimental fens are now under construction in the area.

\subsection{Fluid Fine Tailings}

One of Fort McKay's main concerns with oil sands development is the presence of huge volumes of fluid fine tailings. Tailings are stored in large, constructed ponds, or are pumped into mine pits that have come to the end of their productive life. Oil sands tailings exhibit physical and chemical properties much different from most other mining tailings and as a result oil sands tails are very slow to consolidate and tend to stay in liquid suspension, presenting a barrier to reclamation of these sites. Until recently tailings were treated with a 
combination of sand and gypsum in a process known as consolidated tailings (CT) that in theory increased the rate of tailings consolidation.

In 2009 the ERCB released Directive 074 which addressed some concerns with volume of fluid tails on oil sands sites, directing operators to move towards a drier landscape, by requiring tailings to meet certain strength requirements in a specified time period. To date, oil sands developers have demonstrated that it is possible to manage fluid tailings in a manner that will produce a drier landscape sooner; this has opened the door to faster reclamation times and the need for less tailings ponds. A tailings consortium has also been formed, made up of various oil sands developers. The goal of the consortium is to share tailings knowledge and research to improve overall tailings management in the future.

These recent changes to tailings management will begin to address Fort McKay's concerns regarding both the stability of ponds containing fluid tailings remaining on the landscape at end of mining and the storage of fluid fine tailings in end pit lakes.

\section{Conclusions}

Fort McKay has strong traditional use and spiritual connections to the land that is being mined to extract the Athabasca oil sands. The Community expects to continue to live in this region long after the oil sands projects are completed and therefore they have a large interest and significant concerns with regard to how the lands will be reclaimed. They have shared their concerns and recommendations with regulators and developers and have contributed their traditional knowledge to regional reclamation initiatives and with individual operators. While some of the Community's concerns are being addressed through recently revised regulations and research programs, much is left to be resolved including the formalized involvement of Fort McKay in the reclamation certification decision process.

\section{References}

Alberta Environment, 2009. http://www.oilsands.alberta.ca/reclamation.html

Fitzpatrick, C. 2003. Traditional uses of boreal wetlands. In: Creating Wetlands in Oil Sands Reclamation Workshop Proceedings, October 2003. Fort McMurray, AB.

Fitzpatrick, C. (2004). Re-Creation and Conservation of the Spirit of the Land - Restoration of Ecology and Community in Canada's Boreal Forest. Proceedings of the CLRA and SER, Victoria BC 2004.

Fort McKay Industry Relations Corporation. Fort McKay IRC. Cultural Heritage Assessment Baseline: PreDevelopment (1960s) to Current (2008). October 2010a.

Fort McKay Industry Relations Corporation. 2010a, 2010b. Healing the Earth Strategy.

Garibaldi, A. (2006). Fort McKay - Albian Sands Energy Inc. TEK Project. Integration of traditional environmental knowledge in land reclamation. Prepared by Garibaldi Heritage and Environmental Consulting for Albian Sands Energy Inc. and the Fort McKay IRC. August 2006.

Regional Municipality of Wood Buffalo. (RMWB) 2008. Municipal Census. http://www.woodbuffalo.ab.ca/ Assets/Corporate/Census+Reports/2010+Municipal+Census.pdf 